\author{
赤野裕文
}

（株式会社Mizkan MD本部商品企画部商品企画 1 課）

\title{
The evolution of sushi and the power of vinegar
}

\author{
Hirofumi Akano
}

\author{
Product Planning Dept. Section 1, Merchandising Division, Mizkan Holdings Co., Ltd., \\ 2-6, Nakamura-cho, Handa-shi, Aichi, 475-8585 \\ ₹475-8585 愛知県半田市中村町 2-6
}

\begin{abstract}
Sushi did not become the staple food we eat today, with its vinegared rice and toppings eaten together known as hayazushi (fast sushi), until the mid-Edo period. Prior to this, sushi was usually fermented using lactic acid fermentation. As fermented sushi evolved from honnare (fully fermented sushi), to namanare (partially fermented sushi), to kairyō namanare (improved partially fermented sushi), the fermentation period became shorter. From namanare onwards, fermented sushi went from being simply preserved fish to a dish in which fish and rice are eaten together. Sushi then evolved into hayazushi, and in the late-Edo period, nigirizushi (hand-pressed sushi) was invented in the city of Edo (Tokyo). One of the things that supported the development of nigirizushi culture was red vinegar (aka-su) developed in Handa Bishu (located in modern day Aichi). Red vinegar gets its name from its red color and is made from aged sake lees.

The basic role of acid in sushi is to improve preservation. The antibacterial power of lactic acid in fermented sushi and acetic acid in hayazushi enhance the preservation of sushi. Nowadays, vinegar also plays an important role in improving the taste of sushi.

Sushi has developed greatly in Japan from its origins in Southeast Asia. It has changed according to the environment and time period, and continues to evolve.
\end{abstract}

\section{1.はじめに}

和食は，2013年12月に「和食：日本人の伝統的な食文 化」としてユネスコ無形文化遺産に登録された。現在寿 司は，世界中で食されている和食を代表する人気入 ニューの一つである。寿司が現在のように「酢飯と夕ネ を一緒に食する主食」に変化したのは江戸時代中期であ り，それまでは乳酸発酵を主体とした「発酵ずし」であっ た。本稿では「発酵ずし」から「早ずし（酢を使った寿 司)」への寿司の変遷と，江戸時代後期，江戸に誕生し た握り寿司文化を支えた尾州半田の赤酢について紹介す るとともに，現代の寿司事情についても述べる。また， 寿司に抒ける酸の役割についても触れる。
2. 発酵ずしから早ずしへの変遷

発酵ずしの源流は東南アジアである。ラオス, カンボ ジア, タイなどのメコン川流域やミャンマーのエーラ ワーディ川流域にて淡水魚の保存を目的に作られていた。 日本における発酵ずしの源流となるホンナレ(熟れずし) は，奈良時代以前に登場した滋賀の鮒寿司が有名である。 室町時代になるとナマナレ（生成）と呼ばれる発酵ずし が登場する（写真 1 )。ナマナレはホンナレと比較する と発酵期間が短く，発酵に使用した飯も魚と一緒に食す るようになった。すなわちナマナレの登場により, 発酵 ずしは魚の保存食から魚と飯を食するものに変化した ${ }^{1)}$ といえる。発酵ずしは, ナマナレ登場後も, 発酵期間を 短縮するための工夫がなされてきた。具体的には, 䡘, 酒, 
写真 1 ホンナレとナマナレ

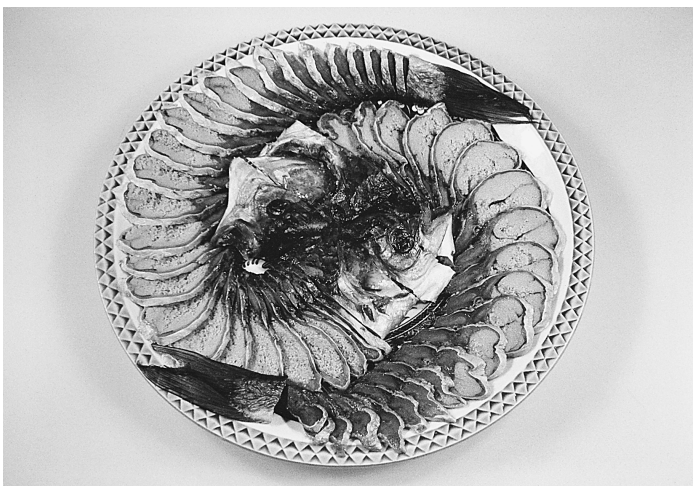

ホンナレ（琵琶湖の鮒寿司）

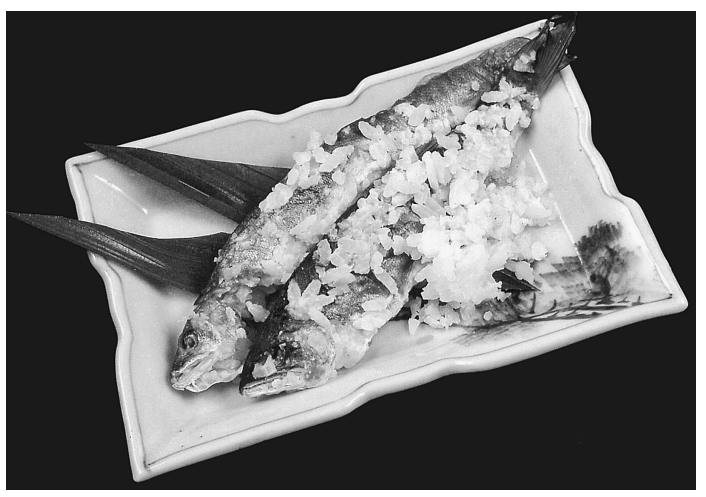

ナマナレ（岐阜の鮎寿司）

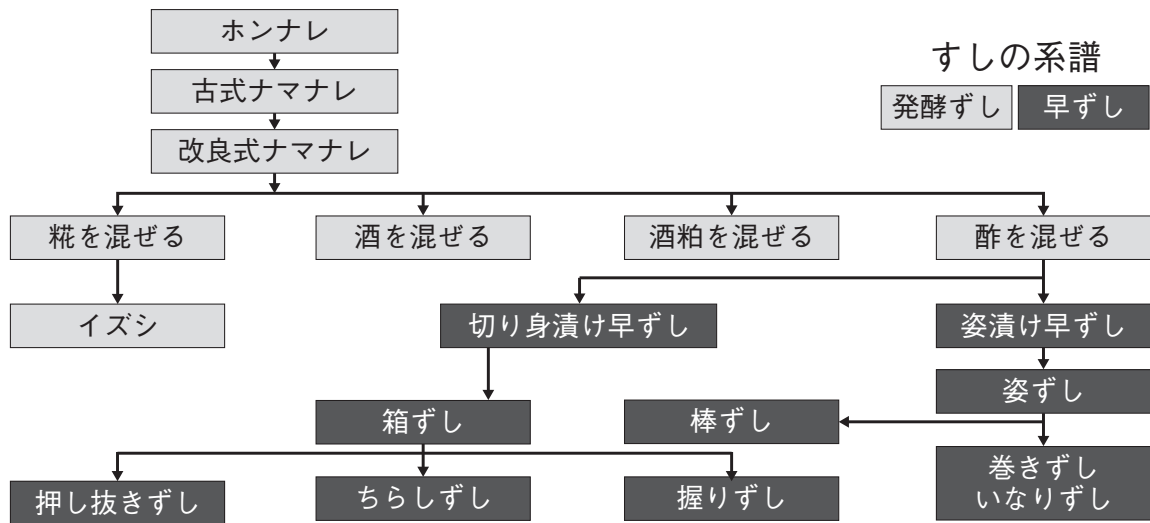

図 1 寿司の系譜

酒粕が発酵促進を目的に使われてきた。そして，江戸時 代の初期には，発酵促進目的に酢を使ったナマナレが登 場した。早ずし誕生以前の発酵寿司の変遷は，いかに発 酵期間を短縮化するかの歴史であるともいえる。そして， 江戸時代中期に究極の短縮化の方法として，発酵するこ となく，発酵食品である酢で酸味を付与する早ずしへと 進化を遂げた（図 1 )。

『合類日用料理抄』（1689年刊）には早ずしという言葉 の記載がある。『料理網目調味抄』（1728年刊）には「箱 寿司に酢を注ぐ」という表現があり，発酵はなされてい ない。また，『献立鉒』では早ずしが「寿司もどき」と 表現されている。『名飯部類』（1802年刊）では「寿司は, 昔は発酵させるものだったが，今では酢を使うものばか り」と解説されている。早ずしの登場後，今でも広く親 しまれている寿司が生まれた。『料理山海郷』(1750年刊) には「巻䱕」の記載がされているが，この中では現在の ように酢飯は巻かれておらず，魚の身と大根おろしを巻 いたものである。酢飯を巻いた巻き寿司は『新撰献立部 類集』（1776年刊）に登場する。『名飯部類』には「起こ し寿司」という寿司が登場する。「起こし寿司」は「箱 ずし」を切り出して食するものではなく, さじですくっ て食べる寿司である。この「起こし寿司」はもともと重 石で押していたが，その後，酢飯を押さない今のちらし 寿司の原型となった。『守貞漫稿』(1837年刊) には,「散
らしごもく䰿」は「起こし寿司」ともいう，と記載され ている（表 1 )。

そして，その後登場した寿司が「握り寿司」である。 握り寿司が文献で登場するのは『俳風柳多留』(1827年刊) で，この中に「妖術という身で握る寿司のめし」とある。 これは，握り寿司は忍術使いが握ったような格好で作ら れていたことを表している。この握り寿司を考案した人 物は諸説あり定かではないが，握り寿司を大成したのは 華屋与兵衛だと考えられている。与兵衛の 4 代目の弟に あたる小泉迂外の著作『家庭＼cjkstart䱕のつけかた』(1910年刊) には初代与兵衛のレシピをもとにした寿司の作り方が記 載されているが, 江戸時代の握り寿司の特徵は以下の通 りである ${ }^{2)}($ 写真 $2 \cdot 3)$ 。

(1) 酢は赤酢を使用し現在の約半量。砂糖は使わず塩 は現在よりやや多目であった。

(2) 酢飯の大きさは現在の約 3 倍と大きかった。

(3) 夕ネはそのまま握るのではなく, 下処理（仕事） されていた。

江戸時代中期に早ずしが誕生した際に使われていた酢 は米酢であったと推察されるが, 握り寿司が登場し普及 する中で, 酢は尾州半田の赤酢「山吹」が使われるよう になった。 
寿司の変遷と酢の力

表 1 江戸時代の寿司に関する出来事

\begin{tabular}{|c|c|c|}
\hline 年 代 & 出 典 & 出来事 \\
\hline 1668年 & 料理塩梅集 & 発酵促進に酒と酢を使う \\
\hline 1689年 & 合類日用料理抄 & 「早ずし」の記載あり \\
\hline 1673年ごろ & 難波江（幕末から明治のころ）より & 「松本ずし」の記載「まちゃれずし」 \\
\hline 1728年 & 料理網目調味抄 & 「箱寿司」に酢をそそぐ。発酵なし \\
\hline 1750年 & 料理山海郷 & 「巻䰻」の文字。飯を巻いていない \\
\hline 1760年 & 献立鉒 & 早ずしが「寿司もどき」的表現 \\
\hline 1776年 & 新撰献立部類集 & 巻寿司製法 浅草海苔, ふぐの皮, 紙で巻く \\
\hline 1804年ごろ & 嬉遊笑覽（1829年刊）より & 「松がずし (いさごずし)」開店 \\
\hline 1818年ごろ & 家庭䰻のつけかた（1910年刊）より推定 & 興兵衛が握り寿司を岡持ちで売る \\
\hline 1825年ごろ & 寿司の雑誌（1990年刊）より推定 & 興兵衛, 両国元町に毎夜屋台 \\
\hline 1827年 & 俳風柳多留 & 妖術という身で握る寿司の飯 \\
\hline 1830年ごろ & 江戸名物詩（1836年刊）より推定 & 興兵衛, 両国元町に興兵衛䰻開店 \\
\hline 1830年ごろ & 守貞漫稿（1837年刊）より & 大坂「福本」が手押しの箱ずし \\
\hline 1843年 & 藤岡屋日記 & 稲荷寿司, 当時流行 \\
\hline 1852年 & 近世商賈尽狂歌合 & 稲荷寿司, 天保の飢饉のころ起こった \\
\hline
\end{tabular}

写真 2 江戸時代の鮓の図（写真）

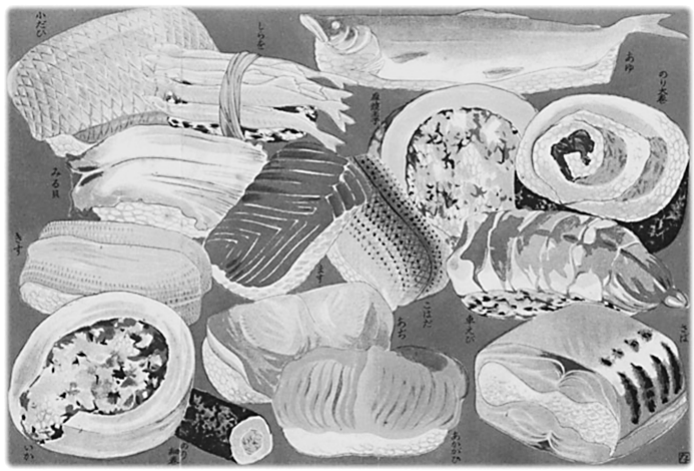

出典 : 小泉清三郎『家庭 鮮のつけかた』

原図：吉野鮨本店所蔵

\section{3. 尾州半田に赤酢「山吹」が誕生}

日本に酢の製法が伝わったのは 4〜5世紀だと考えら れている。酢は酒造りの技術とともに，中国より米酢の 作り方が伝わってきた。米酢は江戸時代には全国各地で 製造され，和泉酢 (大阪)，北風酢 (兵庫), 中原酢（神 奈川), 善徳寺酢 (静岡), 粉河酢 (和歌山) などが知ら れている ${ }^{3)}$ 。米酢全盛の時代に, ミッカン創業者初代中 野又左衛門は，1804年，尾州半田から江戸に下り，早ず しに出会い新しい酢の開発に本格的に着手した。尾州半 田が位置する知多半島は, 江戸時代, 酒, 味噌, たまり 奨油などの醸造業が盛んな土地であった。特に尾張，三 河，美濃，伊勢で造られる酒は，中国酒として大消費地 である江戸に運ばれていた。尾張の中でも，知多半島の 酒は約半量を占めており, 利用されていない酒粕が大量
写真 3 『家庭 䰿のつけかた』をもとに再現した 江戸時代の握り寿司

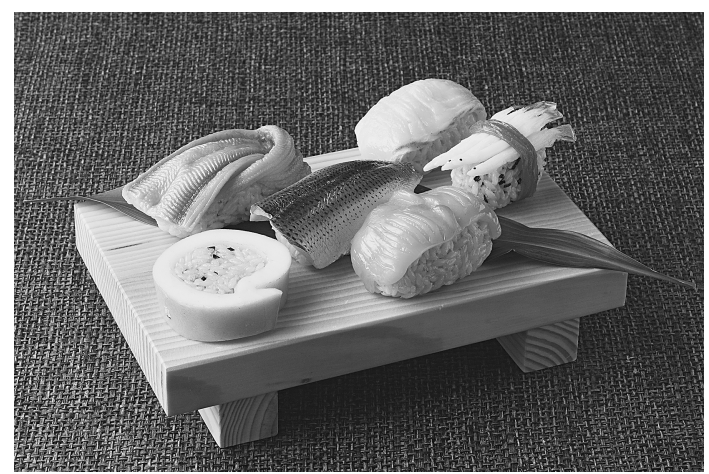

に存在していた。又左衛門はこの酒粕を活用し，米酢に 代わる新しい酢の開発に着手した。又左衛門は原料の酒 粕をそのまま使うのではなく，熟成した酒粕を原料に 使った。酒粕中にはアルコール分のほかに，利用されて いないでん粉やタンパク質が多く残っている。

酒粕は熟成することにより，微生物が作り出す酵素に よりでん粉は糖に, タンパク質はアミノ酸に変化し, そ してこれらの成分は一部メイラード反応により熟成香を 作り出し, そして色は赤褐色へと変化していく。熟成し た酒粕を原料に使うことにより甘み，旨み，香りが醸し 出される。又左衛門は熟成した酒粕から酢を造ることに より，握り寿司にマッチした味わいを実現し，米酢との 差別化を実現した ${ }^{4)}$ 。そしてこの酒粕酢はその色合いか ら「赤酢」と呼ばれるようになった（写真 4$)$ 。 早ずしは，赤酢が登場するまでは，米酢が使われてい 
写真 4 江戸時代当時の赤酢「山吹」

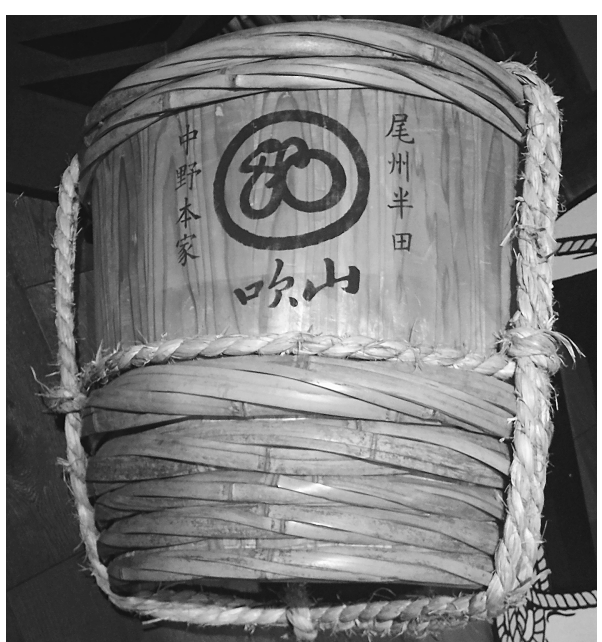

たが、この米酢に大きな環境変化が起こった。それは， 酢の用途として工業用途が加わったことである。『日本 山海名産図絵』（1799年刊）には，酢は食用が少なく， 紅粉，昆布，染色などに用いることがいたって多いと書 かれている。実際，紅花からの紅の染料の抽出や，染物 の色の定着などに使われた。握り寿司需要が増加してい く中で，工業用途でも酢は大量に使用されるようになり 江戸では酢の供給が逼迫していたようである。このよう な時代背景の中，赤酢は江戸の街に定着していった。

\section{4. 明治以降，戦後までの寿司事情}

江戸の街に誕生した握り寿司は，当初江戸の郷土料理 であった。その握り寿司が全国に広がるきっかっけと

\section{写真 5 委託加工制度看板}

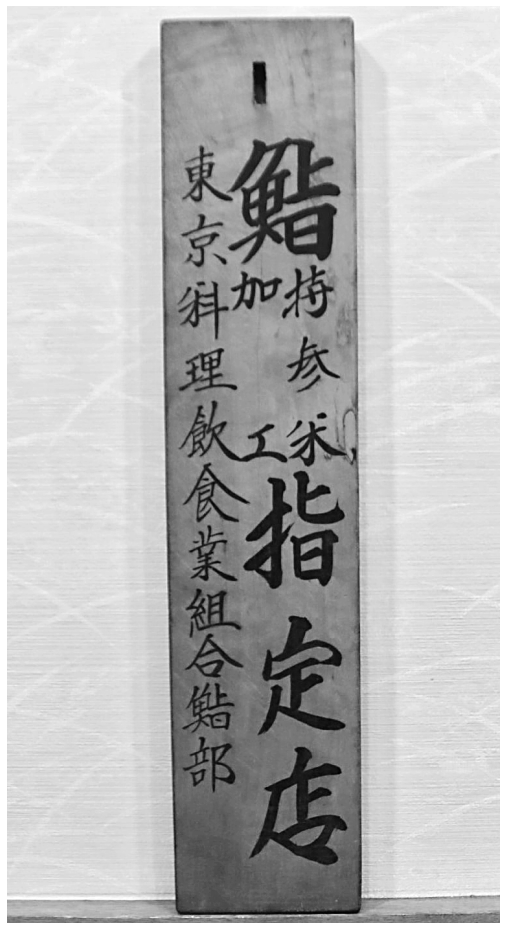

所蔵：浅草宝来鮨
なったのは, 関東大震災と終戦, そして, 戦後の委託加 工米制度であるといえる5)。1923年，首都圈を襲った大 震災は，甚大な被害を与えた。人々の中には東京を離れ 故郷へ帰る, 今でいうUターン現象が起こった。この人々 の中には握り寿司職人もいて，今までやってきた仕事を 故郷で始めようと，握り寿司店を地方で開業するように なった。さらに，震災の約20年後，1945年に終戦をむか えたが，関東大震災後と同様，握り寿司職人が各地に向 かっていった。また，終戦後の食糧難の時代，1947年に, 政府は「飲食営業緊急措置令」を発令した。これにより， 飲食業者は, 米は一切, 売ることも食べさせることもで きなくなった。そんな時, 東京の寿司の組合が,「握り 寿司店の仕事は，寿司を握ることであり，飲食業者では ない。米は客が持ってくるから，米を売っているわけで もない。米飯を寿司に加工する『加工業者』だ」と主張 した。この主張が委託加工制度として認められた。そし て，この働きかけは，全国の寿司の組合に広がり，握り 寿司は全国に広まった（写真 5 )。

\section{5. 現代の寿司事情}

現代の寿司を代表するものとして，回転寿司と節分の 恵方巻きがある。回転寿司のルーツは1958年 4 月に東大 阪市にオープンした「迴る元禄寿司 1 号店」で，人手不 足解消の目的で, ビール工場の製造に使われているベル トコンベアにヒントを得て開発されたといわれている。 「迴る元禄寿司」は1970年に開催された，日本万国博覧 会に出店し，日本中に知られることになった。回転寿司 が人気を博したのは，寿司を乗せた皿が回るという面白 さもあったが，それ以上に，寿司を 1 皿いくらと明記し， しかもそれを低価格に抑えたことにあるといえる。この ことにより，寿司は，手軽な大衆食のイメージを獲得し， 市場が拡大したと考えられる。回転寿司が登場してから 半世紀以上，その人気は今も変わらない。最近では，う どんやそば，ラーメンをはじめドリンク類やデザートま で，たくさんの食べ物が回っている。そして，回転ずし の人気は，国内にとどまらず，世界に広がっている。

節分には「恵方」を向いて，巻きずしを，切らずに丸 のまま食べる，という風習がある。この風習は，もとも と大阪の花街に起源があり，旦那衆がお座敷で芸者たち に命じて，面白おかしく巻きずしを食べさせたものとの 説がある。この風習の最も古いといわれている宣伝チラ シは，1932年に大阪鮨商組合が出したもので，そこには 花柳界にて，もてはやされたと書かれている。また，恵 方を向いて無言で壱本の巻寿司を丸かぶりすれば，その 年は幸運に恵まれるとのご利益も書かれてる（写真 6 )。 その後, 大阪府䰻商環境衛生同業組合のほか, 大阪海苔 問屋協同組合や関西厚焼工業組合など，食材メーカーま でも巻き込んだ一大キャンペーンとして盛り上がりを見 せ，大阪周辺に定着していった。

1989年, 大手コンビニエンスストアが広島県店舗で「恵 
写真 6 恵方巻きの宣伝ちらし

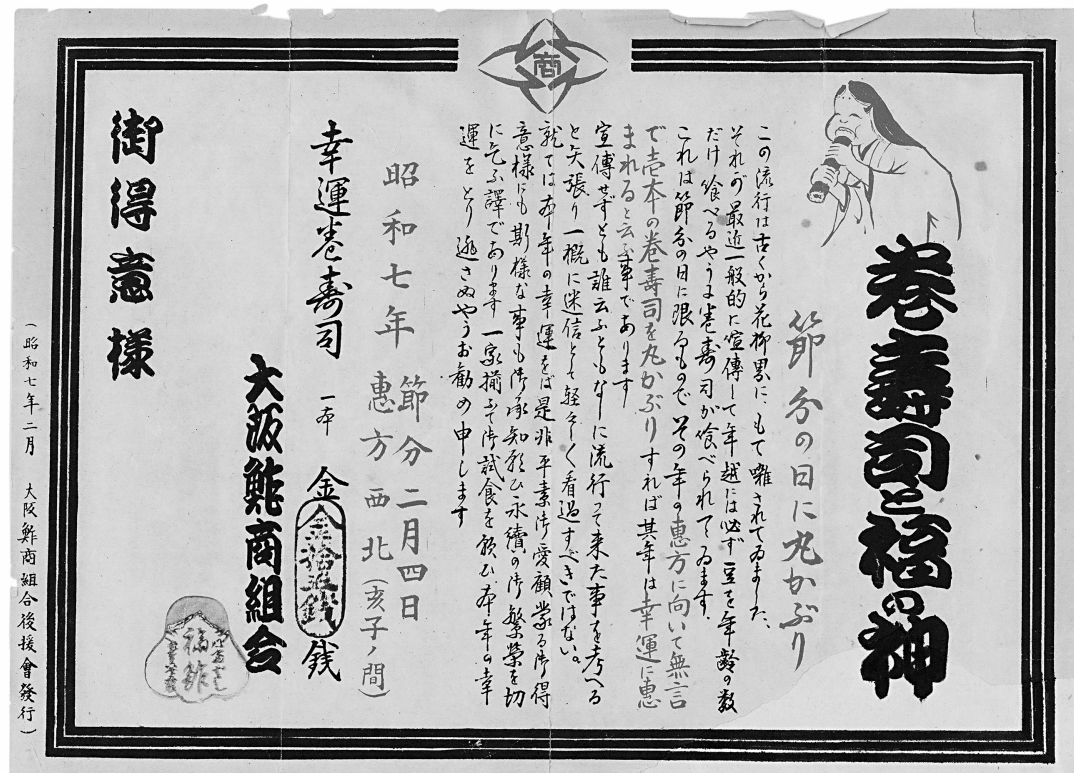

所蔵：清水寿司ミュージアム

表 2 現代の寿司事情

\begin{tabular}{|c|c|c|c|c|c|c|}
\hline & 1960年代 & 1970年代 & 1980年代 & 1990年代 & 2000年代 & 2010年代 \\
\hline 全体 & $\begin{array}{l}\text { 江戸前寿司は高 } \\
\text { 嶺の花 }\end{array}$ & $\begin{array}{l}\text { 「江戸前寿司」 } \\
\text { の大衆化 }\end{array}$ & $\begin{array}{l}\text { 「おすしメニュー」 } \\
\text { の多様化 }\end{array}$ & $\begin{array}{l}\text { 中食, 外食が好 } \\
\text { 調 }\end{array}$ & $\begin{array}{l}\text { 回転寿司が拡大 } \\
\text { メニューの広がり }\end{array}$ & $\begin{array}{l}\text { 回転寿司が定番化 } \\
\text { すし（SUSHI）バラ } \\
\text { エティー化 }\end{array}$ \\
\hline 肉食 & $\begin{array}{l}\text { いなり寿司, 巻 } \\
\text { き寿司, ちらし } \\
\text { 寿司など }\end{array}$ & $\begin{array}{l}\text { いなり寿司, 巻 } \\
\text { き寿司, ちらし } \\
\text { 寿司など }\end{array}$ & $\begin{array}{l}\text { 「手巻き寿司」 } \\
\text { ブーム }\end{array}$ & $\begin{array}{l}\text { 手巻き寿司が定 } \\
\text { 着 }\end{array}$ & $\begin{array}{l}\text { メニューの広がり } \\
\text { (ハレ〜ケまで) }\end{array}$ & $\begin{array}{l}\text { 料理サイト, SNS を } \\
\text { 中心に多様化 }\end{array}$ \\
\hline 外食 & $\begin{array}{l}\text { 「寿司屋」での } \\
\text { 食事 }\end{array}$ & $\begin{array}{l}\text { 「扔寿司屋さん」 } \\
\text { の拡大成長期 }\end{array}$ & $\begin{array}{l}\text { 回転寿司 } \\
\text { チェーン展開始 } \\
\text { まる }\end{array}$ & $\begin{array}{l}\text { 回転寿司 } \\
\text { ネタの大きさと } \\
\text { ボリュームで差 } \\
\text { 別化 }\end{array}$ & $\begin{array}{l}\text { 回転寿司 } \\
\text { 低価格路線と高級路 } \\
\text { 線に }\end{array}$ & $\begin{array}{l}\text { 回転寿司 } \\
\text { ファミリーレストラ } \\
\text { ン化が進む }\end{array}$ \\
\hline 中食 & $\begin{array}{l}\text { 「おすし屋さん」 } \\
\text { の出前, 持ち帰 } \\
\text { り }\end{array}$ & $\begin{array}{l}\text { テイクアウト } \\
\text { 寿司店により } \\
\text { 「しの大衆化」 }\end{array}$ & 品質向上 & $\begin{array}{l}\text { テイクアウト } \\
\text { 最盛期, スー } \\
\text { パーも伸張 }\end{array}$ & $\begin{array}{l}\text { 恵方巻全国化 } \\
\text { コンビニエンススト } \\
\text { アの寿司が伸張 }\end{array}$ & $\begin{array}{l}\text { スーパー寿司のメ } \\
\text { ニュー } \\
\text { バラエティ化が進む }\end{array}$ \\
\hline
\end{tabular}

方巻き」と称して，節分の巻きずしを商品化した。そし てその 7 年後に西日本で, さらにその 3 年後には全国で 販売を展開させ，恵方巻きは全国に広がった（表 2 ）。

\section{6. 寿司における「酢の力」}

発酵ずしは，乳酸発酵により作られる乳酸により，魚 の保存性を高めていた。早ずしは乳酸の代わりに, 酢の 主成分である酢酸の静菌力により, 寿司の保存性を高め ている。このように，寿司に扔ける酸の基本的な役割は， 保存性向上にあったといえる。

現在の寿司に扔いては，酢は保存力とともに，喏好性 向上についても，重要な役割を果たしている。著者らは， 握り寿司の中でも人気の夕ネである，まぐろに着目し， 「まぐろ握り寿司」の㧍いしさに及ぼす酢の影響につい て評価した ${ }^{6)}$ 。まぐろは地中海産養殖中卜ロを使用した。
寿司飯は, 寿司店で多く使用されている米酢（白酢）で 白シャリを，酒粕酢（赤酢）で赤シャリを作成し，白飯， 白シャリ，赤シャリの 3 種類を使用した。嗜好型官能検 查 (順位法)にて評価した結果，寿司飯は白飯よりも扮 いしさ評価が高く，白シャリよりも赤シャリのほうが抒 いしさ評価は高いという結果が得られた。結果は示さな いが，QDA 法から「まぐろ由来の酸味・血の風味（鉄 分)」「魚の脂っぽさ (脂質)」が「まぐろ握りずし」の おいしさに関わる大きな要素として抽出された。白飯と 比べて, 白シャリ, 赤シャリと一緒にまぐろを食べるこ とでそれらが抑制され，さらに，「魚の脂っぽさ」につ いては，赤シャリが有意に抑制されることがわかった。 すなわち，脂がのったまぐろほど赤シャリと相性が良い ことが示唆された（図 2 )。 


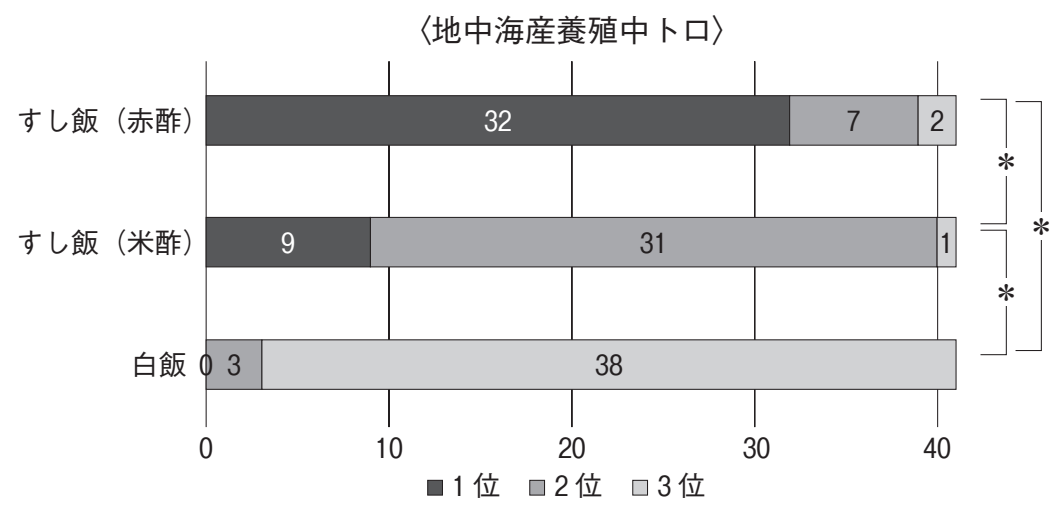

* : 5 \%水準で有意差あり（有意差検定：NEWELL \& MACFARLANE の検定表による)

図 2 まぐろ握り寿司のおいしさ評価の結果

\section{7.おわりに}

寿司は時代の変化の中で進化してきた。今では国内だ けではなく，世界中で新しい寿司がうまれている。寿司 は，今からも環境変化に適応し，生活者に支持されるメ ニューに進化し続けていくと考える。

最後に，本寄稿を執筆するにあたり，寿司の変遷全般 にわたり指導いただいた，愛知淑徳大学 日比野光敏教 授に心より感謝いたします。

\section{文献}

1）日比野光敏：寿司の貌 第 1 版, 大巧社, 東京, p.61 (1997)

2）赤野裕文：「なれずし」から「江戸前寿司」への進化とそ の復元について, 日本調理科学会誌, 41, 214-217 (2008)

3）岩崎信也：世界に広がる日本の酢の文化 第 1 版，凸版 印刷, 東京, p.58 (2003)

4 ）赤野裕文：江戸の握り寿司文化を支えた尾州半田の赤酢, 粉体技術， 10，533-537（2018）

5 ）株式会社 Mizkan：寿司ラボ「寿司の歴史」, http://www. mizkan.co.jp/sushilab/manabu/ (2021年 1月12日閲覧)

6 ) 白石旭, 赤野裕文: 日本調理科学会大会研究発表要旨集, 福岡, p.56 (2019)

本稿は，第61回大会における主題講演をまとめたものである。 